\title{
Synthesis of nano-alumina powder via recrystallization of ammonium alum
}

\section{(Síntese de nanopó de alumina via recristalização de alúmen de amônio)}

\author{
A.N.Saud ${ }^{1 *}$, H.Sh.Majdi ${ }^{2}$, S. N.Saud

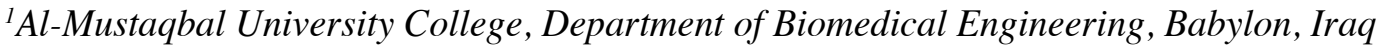 \\ ${ }^{2}$ Al-Mustaqbal University College, Department of Chemical Engineering, Babylon, Iraq \\ ${ }^{3}$ Management and Science University, Faculty of Information Sciences and Engineering, Selangor, Malaysia
}

\begin{abstract}
In the present study, a recrystallization method was implemented to recover alumina powder from ammonium alum crystal. The ammonium alum was completely dissolved in water and treated by ultra-sonication to prevent the agglomeration of the alum crystal. The white precipitate was dried at $150{ }^{\circ} \mathrm{C}$ for $6 \mathrm{~h}$, and calcinations at different temperatures were performed for $2 \mathrm{~h}$. The XRD results indicated the crystalline structure of alumina with two main phases: $\gamma-\mathrm{Al}_{2} \mathrm{O}_{3}$ and $\alpha-\mathrm{Al}_{2} \mathrm{O}_{3}$ at 800 and $1200{ }^{\circ} \mathrm{C}$, respectively. The $\mathrm{N}_{2}$ adsorption/desorption isotherm results indicated that the surface area for the powder in the $\gamma$ phase, which can be applied in catalysts, was $142.5 \mathrm{~m}^{2} / \mathrm{g}$, while, in the $\alpha$-phase, it was $15.3 \mathrm{~m}^{2} / \mathrm{g}$. The morphologies elucidated that the powder particles were widely distributed in the range of $\leq 160 \mathrm{~nm}$ at different calcination temperatures and this may be attributed to increments in the particle agglomeration as the calcination temperature increased.
\end{abstract}

Keywords: alumina, powder, alum, recrystallization method.

Resumo

No presente estudo, um método de recristalização foi implementado para recuperar pó de alumina a partir de cristais de alúmen de amônio. O alúmen de amônio foi completamente dissolvido em água e tratado por ultrassonicação para evitar a aglomeração do cristal de alúmen. O precipitado branco foi seco a $150{ }^{\circ} \mathrm{C}$ por 6 h e as calcinações em diferentes temperaturas foram realizadas durante $2 \mathrm{~h}$. Os resultados de DRX indicaram a estrutura cristalina da alumina em duas fases principais: $\gamma$ - $\mathrm{Al}_{2} \mathrm{O}_{3}$ e $\alpha_{-}-\mathrm{Al}_{2} \mathrm{O}_{3}$ a 800 e $1200{ }^{\circ} \mathrm{C}$, respectivamente. Os resultados da isoterma de adsorção/dessorção de $N_{2}$ indicaram que a área de superfície do pó na fase $\gamma$, que pode ser aplicada em catalisadores, foi de $142,5 \mathrm{~m}^{2} / \mathrm{g}$, enquanto que na fase a foi de 15,3 $\mathrm{m}^{2} / \mathrm{g}$. As morfologias elucidaram que as partículas de pó estavam amplamente distribuídas na faixa de $\leq 160 \mathrm{~nm}$ em diferentes temperaturas de calcinação e isso pode ser atribuído a incrementos na aglomeração de partículas à medida que a temperatura de calcinação aumentou.

Palavras-chave: alumina, pó, alúmen, método de recristalização.

\section{INTRODUCTION}

Alumina ceramic is one of the most significant materials used for structural ceramic. It has received wide attention due to its properties, such as hardness, oxidation resistance, corrosion resistance, excellent abrasion resistance, and high melting point. It was once used widely in many industrial applications, such as automotive, aerospace, catalytic, microelectronic, and energy applications [1]. It is also practical in many present industries, such as the fine metallurgical, optoelectronic, and electronic industries [2, 3]. Presently, $\alpha-\mathrm{Al}_{2} \mathrm{O}_{3}$ has numerous uses in traditional and advanced ceramic applications. It is a significant substrate for the development of semiconductors and superconductors via molecular beam [4]. Alumina occurs in two forms: transition or metastable phases. $\alpha-\mathrm{Al}_{2} \mathrm{O}_{3}$ is the stable phase of alumina, whereas the metastable phases, i.e., chi $(\chi)$, eta $(\eta)$, kappa $(\varkappa)$, theta $(\theta)$, delta $(\delta)$, and gamma $(\gamma)$, depend

* (D) https://orcid.org/0000-0001-6049-387X on the synthesis temperature [5]. The conventional methods for producing $\alpha-\mathrm{Al}_{2} \mathrm{O}_{3}$ incorporate solid-state, thermallyinfluenced transformations from the hydrates of aluminum oxide. The amount of and total transformation to the corundum structure depends on the time and temperature of the thermal treatment [5-7]. Bauxite has been typically utilized to the fabrication of alumina via the Bayer method, whilst non-bauxitic treatments, which are more common in many countries, have been used in an effort to strengthen the unconventional methods used for producing alumina. The raw materials used in non-bauxitic treatments include mica, alum, alunite, fly ash, and sillimanite [8,9]. Ammonium alum is produced by the recovering the alumina from clay, whilst potassium alum is produced via the recovery of alumina from alunite [8]. Ammonium alum $\left[\mathrm{NH}_{4} \mathrm{Al}\left(\mathrm{SO}_{4}\right)_{2} \cdot 12 \mathrm{H}_{2} \mathrm{O}\right]$, a white crystalline double sulfate of aluminum, is used in fireproofing textiles, porcelain cement, water purification, and natural deodorant [10].

There are some studies that have considered the synthesis of alumina from alum, but most of them have utilized direct heat treatments involving different temperatures or 
precipitation methods to obtain pure alumina powder, but the powder obtained in these cases has had large particle sizes with low surface area and has been in need of more chemical materials $[11,12]$. The underlying purpose of the present study is to facilitate the recovery of ammonium alum and produce a large quantity of high-purity alumina powder with an easy and brief cycle chemical technique.

\section{MATERIAL AND METHODS}

Alumina powder was prepared using ammonium alum crystal as the raw material. The ammonium alum suspension was prepared by dissolving $87 \mathrm{~g}$ of alum in 100 $\mathrm{mL}$ of distilled water at $70{ }^{\circ} \mathrm{C}$, then treating it with ultrasonication for $2 \mathrm{~h}$ until fully dissolved. After $2 \mathrm{~h}$ under a cooling process, white, flake-shaped precipitates were formed, which were then filtered and washed in deionized water several times. The powder produced was dried at 150 ${ }^{\circ} \mathrm{C}$ and calcined at $800{ }^{\circ} \mathrm{C}$ to obtain $\gamma$-alumina, then finally transformed to $\alpha-\mathrm{Al}_{2} \mathrm{O}_{3}$ at $1200{ }^{\circ} \mathrm{C}$. The following equation shows the recrystallization reactions $[6,13]$ :

$$
\begin{aligned}
& \mathrm{NH}_{4} \mathrm{Al}\left(\mathrm{SO}_{4}\right)_{2} \cdot 12 \mathrm{H}_{2} \mathrm{O} \rightarrow \mathrm{NH}_{4} \mathrm{Al}\left(\mathrm{SO}_{4}\right)_{2}+12 \mathrm{H}_{2} \mathrm{O} \\
& 2 \mathrm{NH}_{4} \mathrm{Al}\left(\mathrm{SO}_{4}\right)_{2} \rightarrow \mathrm{Al}_{2}\left(\mathrm{SO}_{4}\right)_{3}+2 \mathrm{NH}_{3}+\mathrm{H}_{2} \mathrm{O}+\mathrm{SO}_{3} \\
& \mathrm{Al}_{2}\left(\mathrm{SO}_{4}\right)_{3} \rightarrow \mathrm{Al}_{2} \mathrm{O}_{3}+3 \mathrm{SO}_{3}
\end{aligned}
$$

The X-ray diffractometer (XRD 6000, Shimadzu, Japan) was used to identify the phases of the alumina powder at room temperature using $\mathrm{CuK} \alpha$ radiation $(\lambda=1.5405 \AA)$ and a scanning range from $20^{\circ}$ to $70^{\circ}$. The scanning rate used was $5 \% \mathrm{~min}$, and the applied power was $40 \mathrm{kV} / 30 \mathrm{~mA}$. Infrared (FTIR) spectra of samples were recorded (Shimadzu 1800, Japan) to evaluate the molecular structure of the functional group in the inorganic materials. The $\mathrm{N}_{2}$ adsorption/ desorption isotherms were obtained via a QSURF surface area analyzer. Prior to performing the test, the samples were degassed at $200{ }^{\circ} \mathrm{C}$ under vacuum inside the apparatus. The isotherms were measured at the temperature of liquid nitrogen $(77 \mathrm{~K})$ in order to identify their surface areas. Field emission scanning electron microscopy (FE-SEM, Zeiss, LEO 1530) was carried out in order to identify the morphologies of the as-synthesized powder particles. In order to confirm the purity of the resultant powder, the energy dispersive spectrometer (EDS, Bruker) was utilized. Observations concerning the morphologies and sizes of the particles were carried out via transmission electron microscopy (TEM, Jeol, JEM-ARM 200F).

\section{RESULTS AND DISCUSSION}

Fig. 1 displays the XRD results for the alumina powder prepared via the recrystallization of alum. It was clearly observed that the diffraction patterns increased slightly when examining the degrees of sharpness of the peaks with increasing the calcination temperature. In addition, in the diffraction pattern of the alumina powder before heating boehmite phase showed very broad peaks, which indicated that the crystallinity of the alumina powder was low (amorphous). The other diffraction pattern in the $\gamma$-alumina phase showed the same trends; they were narrow compared with the pattern of the alumina before calcination due to the increase in the crystallinity of the alumina powder. The increase in calcination temperature led to a transformation from $\gamma$ to $\alpha$ alumina $[14,15]$. The stable phase (corundum) appeared after calcination at $1200{ }^{\circ} \mathrm{C}$. The obtained diffraction data matched fully with JCPDS files 10-0173 and 50-0741, which confirmed the presence of $\gamma$ and $\alpha-\mathrm{Al}_{2} \mathrm{O}_{3}$,
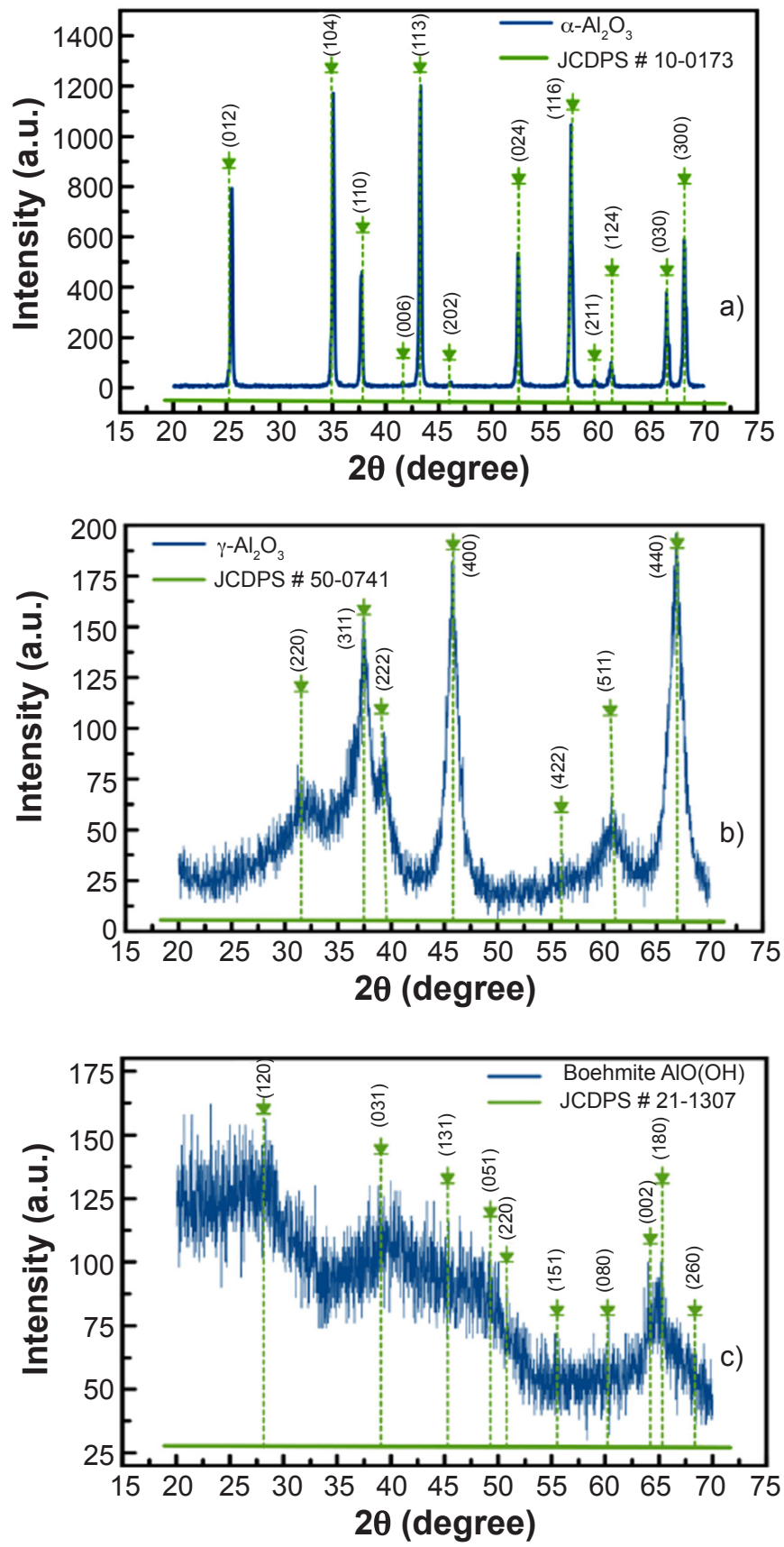

Figure 1: XRD patterns of: a) $\alpha-\mathrm{Al}_{2} \mathrm{O}_{3}$; b) $\gamma-\mathrm{Al}_{2} \mathrm{O}_{3}$; and c) boehmite. [Figura 1: Padrões de DRX de: a) $\alpha-\mathrm{Al}_{2} \mathrm{O}_{3}$; b) $\gamma-\mathrm{Al}_{2} \mathrm{O}_{3}$; e c) boehmita.] 


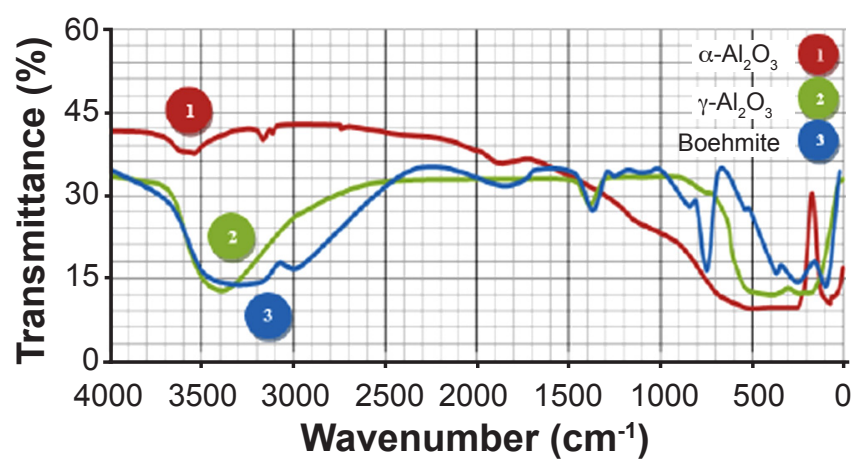

Figure 2: FTIR spectra of the prepared alumina powder calcined at different temperatures.

[Figura 2: Espectros de FTIR do pó de alumina calcinado em diferentes temperaturas.]

Table I - Bond attributions of alumina powder. [Tabela I - Atribuições de ligações do pó de alumina.]

\begin{tabular}{ccc}
\hline $\begin{array}{c}\text { Peak position } \\
\left(\mathrm{cm}^{-1}\right)\end{array}$ & Band & Ref. \\
\hline 594,447 & Al-O bending vibration & {$[13]$} \\
640 & Stretching vibration of Al-O band & {$[14]$} \\
$3300-3510$ & Stretching vibration of O-H band & {$[15]$} \\
2866,2924 & Stretching vibration of C-H band & {$[13]$} \\
\hline
\end{tabular}

respectively [16]. Fig. 2 shows the infrared spectra of pure alumina powder prepared at $1200{ }^{\circ} \mathrm{C}$ for $2 \mathrm{~h}$. The main absorption peaks shown in Fig. 2 and listed in Table I were located at $\sim 594$ and $\sim 447 \mathrm{~cm}^{-1}$, which referred to the Al-O bending vibration of the $\mathrm{Al}-\mathrm{OH}$ groups. In addition, $640 \mathrm{~cm}^{-1}$ peak represented the stretching vibration of the Al-O band and identified the typical absorption band of $\alpha-\mathrm{Al}_{2} \mathrm{O}_{3}, \sim 3300-3510$ $\mathrm{cm}^{-1}$ represented the broadening vibration of the $\mathrm{O}-\mathrm{H}$ bands, and the stretching vibrations of the $\mathrm{C}-\mathrm{H}$ band were located at $\sim 2866$ and $\sim 2924 \mathrm{~cm}^{-1}$ [17-19].

Fig. 3 displays the FE-SEM micrographs of pure alumina powder calcined at 800 and $1200{ }^{\circ} \mathrm{C}$ with a heating rate of $5{ }^{\circ} \mathrm{C} / \mathrm{min}$ and soaking time of $2 \mathrm{~h}$. The SEM images illustrate the influence of the calcination temperature on the

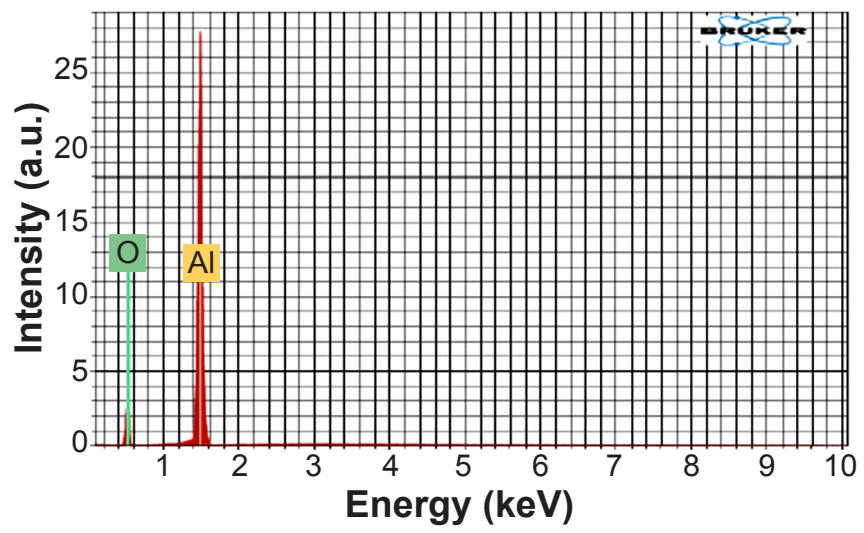

Figure 4: EDS spectrum for $\mathrm{Al}_{2} \mathrm{O}_{3}$ powder calcined at $1200{ }^{\circ} \mathrm{C}$. [Figura 4: Espectro de EDS do pó de $\mathrm{Al}_{2} \mathrm{O}_{3}$ calcinado a $1200^{\circ} \mathrm{C}$.]
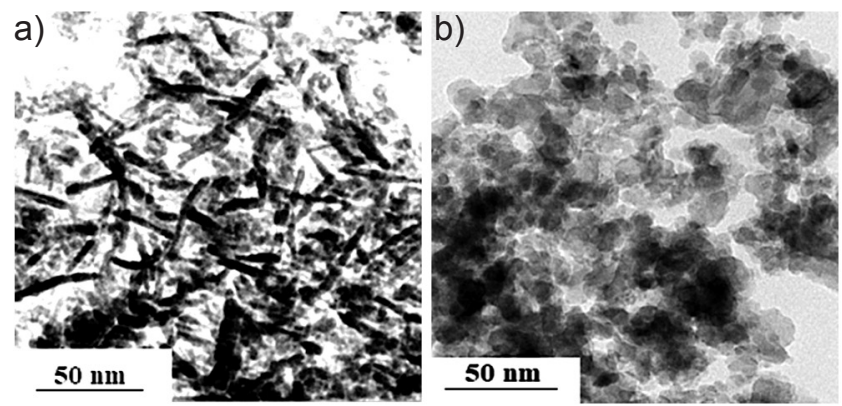

Figure 5: TEM micrographs of $\mathrm{Al}_{2} \mathrm{O}_{3}$ powder calcined at different temperatures: a) $\gamma-\mathrm{Al}_{2} \mathrm{O}_{3}$ at $800{ }^{\circ} \mathrm{C}$; and b) $\alpha-\mathrm{Al}_{2} \mathrm{O}_{3}$ at $1200{ }^{\circ} \mathrm{C}$.

[Figura 5: Micrografias de MET do pó de $\mathrm{Al}_{2} \mathrm{O}_{3}$ calcinado em diferentes temperaturas: a) $\gamma-\mathrm{Al}_{2} \mathrm{O}_{3}$ a $800{ }^{\circ} \mathrm{C}$; e b) $\alpha$ - $\mathrm{Al}_{2} \mathrm{O}_{3}$ a $1200{ }^{\circ} \mathrm{C}$.]

morphology of $\gamma$ and $\alpha$-alumina prepared powders. It can be seen that when the calcination temperature rose from 800 to $1200{ }^{\circ} \mathrm{C}$, the morphology of the alumina powder changed from practically spherical to vermiform in shape and the particles were extremely arranged and attached to each other, leading to an increase in particle size. The alumina powder size increased from 70 to $160 \mathrm{~nm}$ due to the coalescence and the densification of the preliminary particles [12]. Fig. 4 illustrates the EDS results for alumina powder prepared at $1200{ }^{\circ} \mathrm{C}$ for $2 \mathrm{~h}$. The analysis showed clearly the existence
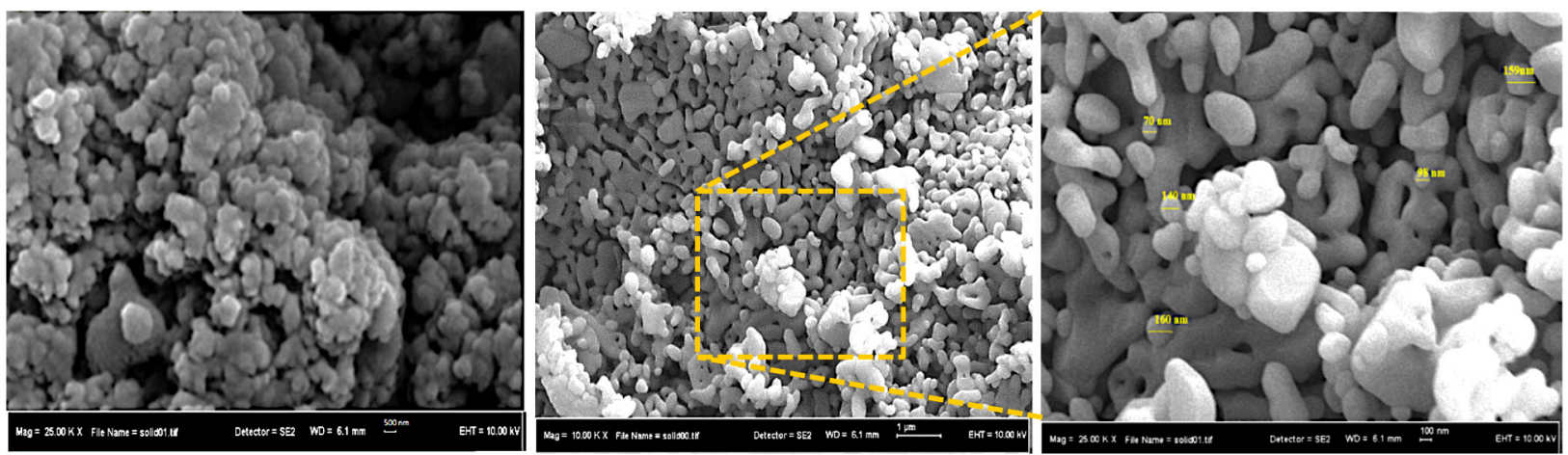

Figure 3: SEM micrographs of $\mathrm{Al}_{2} \mathrm{O}_{3}$ powder calcined at different temperatures: a) $800{ }^{\circ} \mathrm{C}$; and b,c) $1200{ }^{\circ} \mathrm{C}$.

[Figura 3: Micrografias de $\mathrm{MEV}$ do pó de $\mathrm{Al}_{2} \mathrm{O}_{3}$ calcinado em diferentes temperaturas: a) $800{ }^{\circ} \mathrm{C}$; e b,c) $1200{ }^{\circ} \mathrm{C}$.] 
of $\mathrm{Al}$ and $\mathrm{O}$. It was found that the $\alpha$-alumina was chemically pure (no detectable impurities), and this finding was in good agreement with the XRD pattern. Fig. 5 shows the TEM micrographs of $\alpha-\mathrm{Al}_{2} \mathrm{O}_{3}$ powder after different calcination temperatures. According to Fig. 5a, the $\gamma$-alumina particles had a needle-like morphology; however, Fig. 5b illustrates the uniform distribution of the particle size in $\alpha-\mathrm{Al}_{2} \mathrm{O}_{3}$, with an average size of $<50 \mathrm{~nm}$. The morphology of the produced powder is vital to the nanocrystalline structure of $\alpha-\mathrm{Al}_{2} \mathrm{O}_{3}$, in which small particles tend to eventually form the surface of the powder, inducing a spherical-like morphology [20]. On the other hand, the flake morphology refers mainly to the minimum contact points, which help diffusion take places for other possible reactions; therefore, the phase transformation occurs as the grain growths. In spite of this, the stacking orientation and timing of the flake layers are preserved during the calcination and consequently result in the formation of $\gamma-\mathrm{Al}_{2} \mathrm{O}_{3}$ with a rod-like morphology [21,22].

Table II lists the surface area results for the alumina powder calcined at different temperatures. It can be seen that the $\gamma-\mathrm{Al}_{2} \mathrm{O}_{3}$ had a greater surface area than the $\alpha-\mathrm{Al}_{2} \mathrm{O}_{3}$. This result was due to the increase in the calcination temperature, which led to the agglomeration of the $\alpha-\mathrm{Al}_{2} \mathrm{O}_{3}$ particles and prevented the $\mathrm{N}_{2}$ gas molecules from moving freely between the particles [23].

Table II - Surface area of prepared alumina powders. [Tabela II - Área superficial dos pós de alumina preparados.]

\begin{tabular}{ccc}
\hline Sample & $\begin{array}{c}\text { Calcination } \\
\text { temperature }\end{array}$ & $\begin{array}{c}\text { BET surface area } \\
\left(\mathrm{m}^{2} / \mathrm{g}\right)\end{array}$ \\
\hline 1 & $800{ }^{\circ} \mathrm{C}\left(\gamma-\mathrm{Al}_{2} \mathrm{O}_{3}\right)$ & 142.5 \\
2 & $1200^{\circ} \mathrm{C}\left(\alpha-\mathrm{Al}_{2} \mathrm{O}_{3}\right)$ & 15.3 \\
\hline
\end{tabular}

\section{CONCLUSIONS}

In this work, nano-sized alumina ceramic powders have been prepared successfully with a shortened cycle route using recrystallization of ammonium alum. The use of recrystallization of ammonium alum method proved to be very effective for the synthesis of alumina ceramic powder. XRD analyses identified $\gamma-\mathrm{Al}_{2} \mathrm{O}_{3}$ phase at 800 ${ }^{\circ} \mathrm{C}$, and $\alpha-\mathrm{Al}_{2} \mathrm{O}_{3}$ was completely formed at $1200{ }^{\circ} \mathrm{C}$. The preparation of the alumina precursor as recrystallization of ammonium alum that has been treated by ultra-sonication had a significant effect on the resulting alumina particle shape and in the formed alumina phases. The SEM and TEM micrographs showed the microstructures of the synthesized alumina powders, which had regular and nearly sphericallike structure at $1200{ }^{\circ} \mathrm{C}$ and needle shape at $800{ }^{\circ} \mathrm{C}$, with diameters ranging from 70 to $160 \mathrm{~nm}$. The $\mathrm{N}_{2}$ adsorption/ desorption (BET) surface area for the synthesized powder of $\gamma-\mathrm{Al}_{2} \mathrm{O}_{3}$ was $142.5 \mathrm{~m}^{2} / \mathrm{g}$, while it was $15.3 \mathrm{~m}^{2} / \mathrm{g}$ for $\alpha-\mathrm{Al}_{2} \mathrm{O}_{3}$. The difference in surface area between the two phases was attributed mainly to the increase in agglomeration, which led to an increase in the $\alpha-\mathrm{Al}_{2} \mathrm{O}_{3}$ particle sizes.

\section{REFERENCES}

[1] S.J. Cho, B.J. Hockey, B.R. Lawn, S.J. Bennison, J. Am. Ceram. Soc. 72 (1989) 1249.

[2] M. Munro, J. Am. Ceram. Soc. 80 (1997) 1919.

[3] H. Hubner, E. Dorre, Alumina: processing, properties and applications, Spring-Verlag, Heidelberg (1984).

[4] P. De Souza Santos, H. De Souza Santos, S. Toledo, Mater. Res. Bull. 3 (2000) 104.

[5] S. Cava, S. Tebcherani, I. Souza, S. Pianaro, C. Paskocimas, E. Longo, J.A. Varela, Mater. Chem. Phys. 103 (2007) 394.

[6] T. Truex, R. Hammerle, R. Armstrong, Thermochim. Acta 19 (1977) 301.

[7] S. Tabesh, F. Davar, M.R. Loghman-Estarki, J. Alloys Compd. 730 (2018) 441.

[8] S.A. Hosseini, A. Niaei, D. Salari, Open J. Phys. Chem. 1 (2011) 23.

[9] L. Edomwonyi-Otu, B. Aderemi, J. Res. Eng. 6 (2009) 105.

[10] D. Schlain, J.D. Prater, S. Ravitz, Ind. Eng. Chem. 39 (1947) 74.

[11] B. Ebin, S. Gurmen, in Eur. PM Conf. Proc., Eur. Powder Metall. Ass. (2010) 1.

[12] H. Park, Y. Park, R. Stevens, Mater. Sci. Eng. A 367 (2004) 166.

[13] H. Papazian, P. Pizzolato, R. Orrell, Thermochim. Acta 4 (1972) 97.

[14] M.A.A. Al-Dujaili, S. Jaheel, H.N. Abbas, J. Austr. Ceram. Soc. 53 (2017) 41.

[15] S. Tabesh, F. Davar, M.R. Loghman-Estarki, Ceram. Int. 43 (2017) 10247.

[16] M.A. Aswad, A.N. Saud, in IEEE $1^{\text {st }}$ Int. Conf. Recent Trends Eng. Sci. Sustainab., Baghdad (2017).

[17] A. Boumaza, A. Djelloul, F. Guerrab, Powder Technol. 201 (2010) 177.

[18] K. Prem Ananth, S. Shanmugam, S.P. Jose, A.J. Nathanael, T.H. Oh, D. Mangalaraj, A.M. Ballamurugan, J. Asian Ceram. Soc. 3 (2015) 317.

[19] C. Ma, Y. Chang, W. Ye, W. Shang, C. Wang, J. Colloid Interface Sci. 317 (2008) 148.

[20] M. Kumagi, G. Messing, J. Am. Ceram. Soc. 67 (1984) c230.

[21] D. Jiang, Y. Zeng, M. Singh, J. Heinrich, Ceramic materials and components for energy and environmental applications, John Wiley Sons (2010).

[22] H.-J. Youn, J.W. Jang, I.-T. Kim, K.S. Hong, J. Colloid Interface Sci. 211 (1999) 110.

[23] J. Mouzon, "Synthesis of ytterbium-doped yttrium oxide nanoparticles and transparent ceramics", Dr. Thesis, Luleå Un. Technol. (2006).

(Rec. 03/10/2018, Rev. 06/12/2018, 22/12/2018, Ac. 23/12/2018)

(cC) BY-NC 